\title{
橋脚ケーソン設置支䍔のための超音波ドップラー 流速計による流況観測
}

\author{
多田彰秀*・福本 正*・西田秀紀*・高村浩彰*
}

\section{1. はじめに}

流れが速い海峡や水道での橋脚ケーソン設置工事は, 従来から起重機船や鋼款ケーソンに作用する潮流荷重が 最小となる小潮時の潮止りに行われてきた。このため, 小潮時の潮止りを精度良く予測することは, 施工計画上 並びに工程管理上の観点から重要である。一般的には, 工事開始前に対象海域の海面付近で潮流に関する 15 昼 夜連続観測を実施し, 得られたデー夕の調和解析より潮 止りの時刻を予測している.

長崎県西彼杵半島の寺島水道に架設される大島大橋の 橋脚 $3 \mathrm{P}$ および $4 \mathrm{P}$ の建設に際しても上述の方法が採用 され, 海面下 $2 \mathrm{~m} て ゙$ 潮流観測が実施された。さらに, 図一 1 に示すように寺島水道が複雑な海底地形を有している ことから, 海底面上 $5 \mathrm{~m}$ での潮流観測も同時に試みた。 その結果, 寺島水道の潮流は 3 次元的な構造を有する可 能性が極めて高く, それがケ・ソン設置時の安全性や設 置精度に支障を来たすものと懸念された。このため, 超 音波ドップラー流速計（以後 $\mathrm{ADCP}$ と呼ぶ）を導入して 流況に関する詳細な観測を実施することとなった。

本研究では, まず, 試行的になされた海底面上 $5 \mathrm{~m} て ゙$ の潮流観測から確認できた寺島水道に扔ける流動特性に ついて述べる. 次いで, ADCPを用いた流況に関する詳 細な現地観測から, 潮止り前後における流れの反転現象 などについて考察する. 最後に, ADCP の観測結果に基 づく小潮時の潮止り時刻に関する予測方法を提案し，そ れを大島大橋 $3 \mathrm{P}$ および $4 \mathrm{P}$ ケーソン設置工事に適用し た結果について報告する。

\section{2. 海底面近傍での潮流観測}

\section{（1）潮流観測の概要}

海底面近傍の潮流に関する観測は，図一1に示すよう な寺島水道東側の工事海域北端に位置する観測点 St. A （図一1 中の○, 水深約 $25 \mathrm{~m}$ ) で行った. 観測に際しては, 水圧計付きメモリ一電磁流速計（アレック電子社製 ACM-16M3）を海底面上約 $5 \mathrm{~m}$ の位置に係留し, 潮位, 流向・流速並びに水温の時間的変化を自動計測した。観

\footnotetext{
*正会員 工修 西松建設(株)技術研究所
}

測期間は, 1995 年 7 月 5 日 $10: 50$ から 7 月 26 日 $15: 30$ までの約 21 日間である.

また，観測点 St. Aの西側に位置する観測点 St. B (図一1 中の , 水深約 $18 \mathrm{~m}$ ) に扔いては, アーンデラー 流速計（RCM-7）を用いて，海面下 $2 \mathrm{~m}$ での潮流観測が 1995 年 7 月 6 日 $10 ： 30 \sim 7$ 月 21 日 $10 ： 20$ 亿渡って実 施された。

\section{（2）観測結果の考察}

図一2 は, 観測点 St. A およびSt. B で計測された流速 の絶対值 $\left(V_{a}\right)$ の発生頻度を示したものである. $60 \mathrm{~cm} / \mathrm{s}$ を境にして両者の定量的な傾向が異なっている.すなわ ち, $V_{a} \geqq 60 \mathrm{~cm} / \mathrm{s}$ の範囲では, 海面下 $2 \mathrm{~m}$ での流速の発 生頻度が海底面上 $5 \mathrm{~m}$ でのそれよりも大きい值となっ ている. 一方, $V_{a}<60 \mathrm{~cm} / \mathrm{s}$ の領域では, 前者の方が後 者の頻度より小さい，これは，流速の大きな流れが海底 面近傍よりも海面付近で出現しやすいものと解秎され る.

図一3(a) および（b）は，海底面上 $5 \mathrm{~m}$ で計測された 流速の北方分速 (N-S 成分) および東方分速 (E-W 成分) のパワースペクトルを示したものである. 両図からは, 24 時間および 12 時間に対応する周期帯において顕著な スペクトルのピークが認められ, 特に半日潮 $\left(M_{2}\right.$ 潮) が 卓越していることが確認される。ささらに, 両者のエネル ギーレベルを比較してみると, 北方分速の方が東方分速

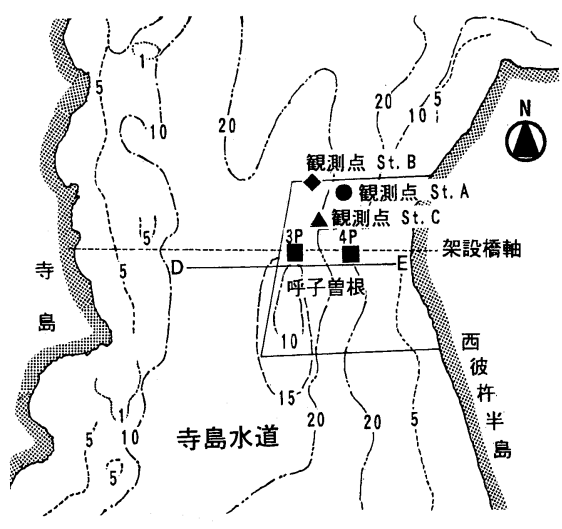

図一1 潮流観測の対象海域 


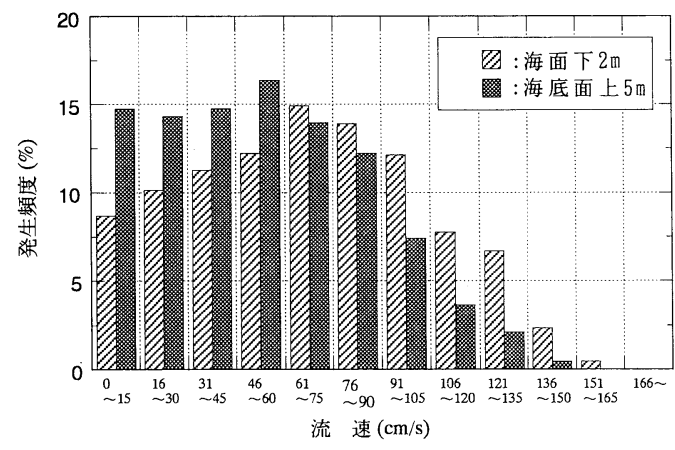

図一2 流速階級別発生頻度

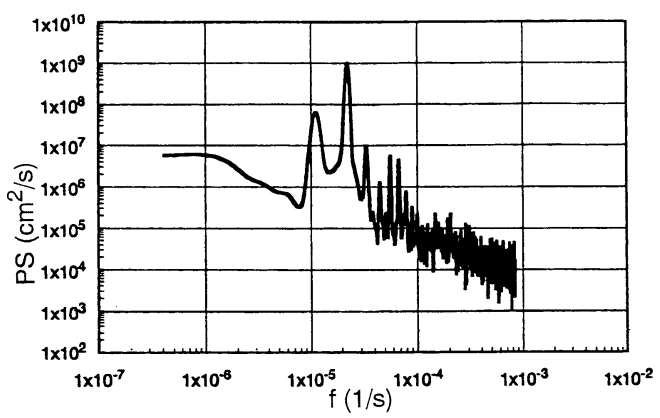

（a）北方分速（N-S 成分）

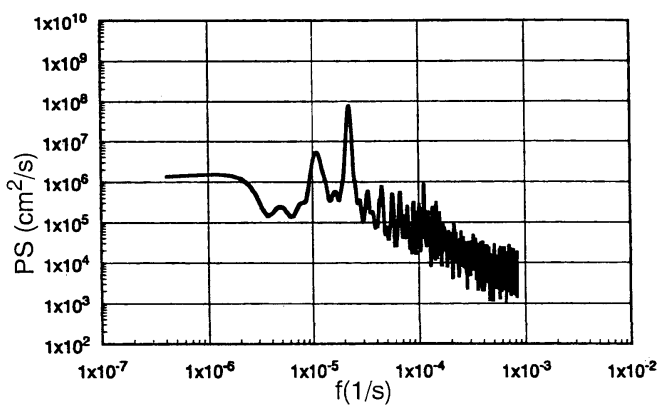

（b）東方分速（E-W 成分）

図一3 潮流流速のパワースペクトル（海底面上 $5 \mathrm{~m}$ ）

より1オーダー高い値を示している，同様のことは，海 面下 $2 \mathrm{~m}$ で計測された流速のパワースペクトルにおい ても得られている. 以上のことから, 寺島水道の潮流は 海面から海底面までほぼ南北方向の往復流が卓越してい るものと断言できる.

図-4 は，観測期間中の小潮時（ 7 月 20 日）に，海面 下 $2 \mathrm{~m}$ (実線) および海底面上 $5 \mathrm{~m}$ (破線) で観測された 北方分速 (N-S 成分) の時間変化を示したものである. 図中に示す○印の箇所からは，海面近傍での潮止りと海 底面近傍の潮止りとの間に約 30 分程度の時間差が存在 していることが読み取れる。このことは，寺島水道に流

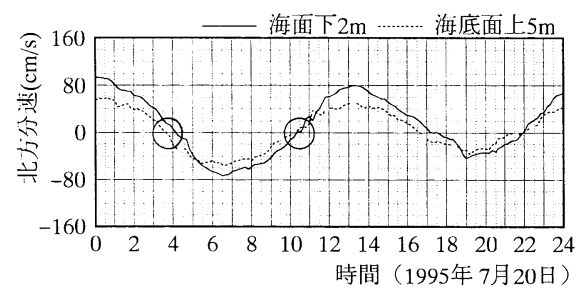

図-4 海面下 $2 \mathrm{~m}$ および海底面上 $5 \mathrm{~m}$ の北方分速（N-S 成 分)

れの 3 次元構造が存在することを示唆している.これに よって,ケーソンに作用する潮流荷重が鉛直方向に均等 でなくなるものと考えられ, 安全性や設置精度などの低 下をもたらすものと懸念される，このようなことから， $\mathrm{ADCP}$ を導入して寺島水道の流況観測を行い, 詳細な検 討を加えることとなった。

\section{ADCP を用いた流況観測}

近年，沿岸域の流れを可視化する目的で，ADCPを用 いた現地観測が盛んに行われている（藤原ら，1989；杉 山ら，1995）。これは, ADCP が走航しながら鉛直方向の 流速分布を多層同時に訃測することがでさるという特徵 を有しているためである，ここでは，寺島水道における 流れの 3 次元的な特性を解明するために $\mathrm{ADCP}$ を導入 して流況観測を実施した.

\section{（1）観測日時および観測対象海域}

ADCP (RD Instruments 社製， $600 \mathrm{kHz}$ トランスデュ サー, ブロードバンド)を用いた流況観測を $3 \mathrm{P}$ ケーソン 設置時（1995 年 10 月 31 日）とほほ同じ月齢の小潮時 （1995 年 10 月 4 日 9：00～15：30）に実施した.なお,こ の時は架設橋軸より北側に位置する観測点 St. C (図一1 中の $\Delta$, 水深 $21 \mathrm{~m}$ ) に作業船を係留して定点観測を行っ た.

\section{（2） 観 測方 法}

水中コネクターが接続した ADCP を観測用作業船（2 $\mathrm{t} \sim 3 \mathrm{t}$ クラスの漁船）の舷側に取り付け，観測時には下 降，移動時には気中へ上昇させることのできる可動式架 台を導入した。観測に際しては, 水深 $3 \mathrm{~m} \sim 4 \mathrm{~m}$ を第 1 層 とするとともに, 平均化時間を 5.1 秒, 層厚を $1 \mathrm{~m}$ とし て計 22 層で流速を同時計測した。 なお, 観測位置の確認 にはGPSを用いている。

\section{(3) 観測結果の考察}

図一5 は, 観測点 St. C で計測された潮流速の北方成分 (N-S 成分) の鉛直分布に関する時間的変化を示したも のである.図より，時間の経過とともに流速 (N-S 成分) が南流から北流へと反転する過渡現象を理解することが できる.特に, 潮止り前後では水深 $15 \mathrm{~m} \sim 18 \mathrm{~m}$ 近傍の流 


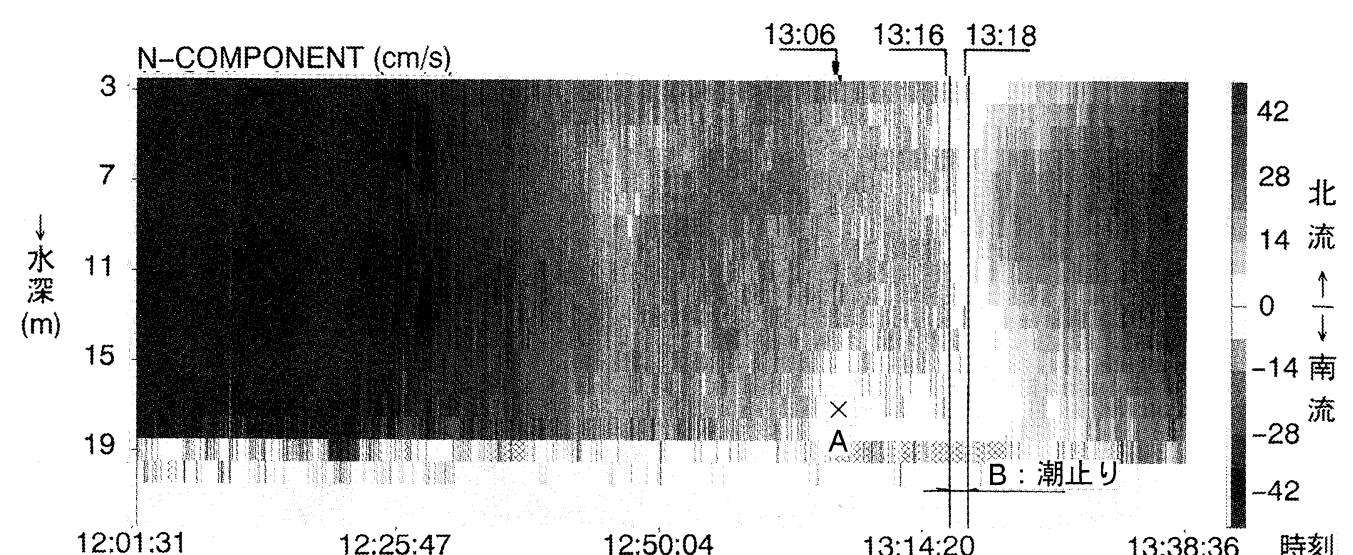

$12: 01: 31$

$12: 25: 47$

$12: 50: 04$

$13: 14: 20$

13:38:36 時刻

図一5 流速分布（N-S 成分）の時間的変化（10月 4 日）

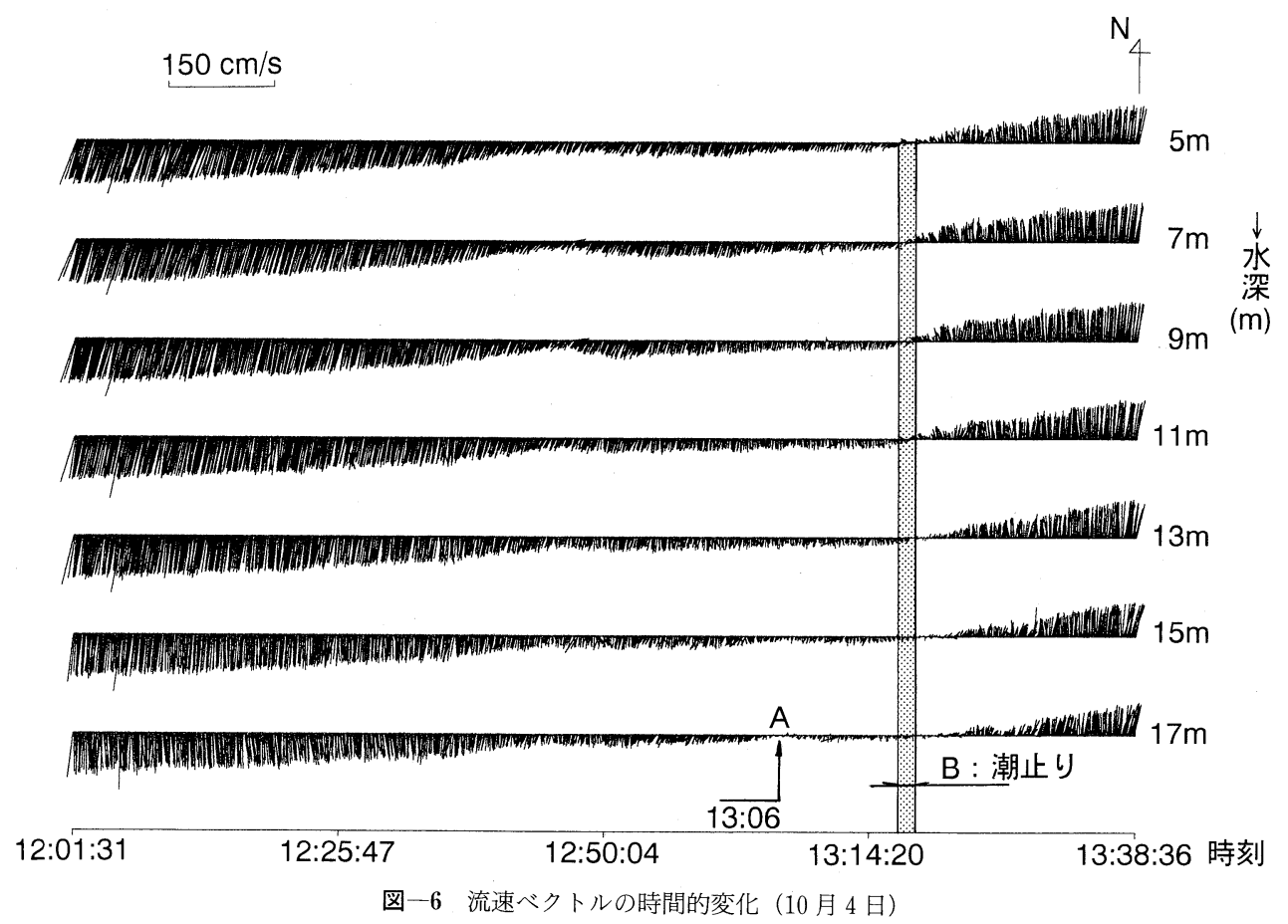

れが先行して微弱となり,その後, 水深 $10 \mathrm{~m}$ 以浅の流れ がほほ停止状態となっている。次いで, 海面から海底面 まで一様な微速状態(図一5 中の白い部分, $13 ：$ 16〜13： 18）が短時間（2 分 30 秒程度）現れた後，水深 $7.0 \mathrm{~m} \sim$ $11.0 \mathrm{~m}$ の中層部から北流に転じている. 全層が北流に転 じた後は, 減速時 (南流 $\rightarrow$ 潮止り)よりも短時間で $50 \mathrm{~cm} /$ $\mathrm{s}$ 近い流速に達していることも分かる.

さらに，図一6 は各水深で観測された流速べクトルの 時間的変化を示したものである. ADCP の観測結果に基 づいて特定された潮止り $(13: 16 \sim 13: 18$, 図一6 中の網
掛け部分）前後では，流速ベクトルが回転していること が確認される、しかしながら，流速が小さいためにケー ソン設㯰時には殆ど問題にならないものと判断される.

4. 橋脚 ケーソン設置支援ツールとしての ADCP の利用

（1）ADCP の観測結果を用いた潮止りの予測方法 寺島水道東側の工事海域で流れが南流から北流に転じ る場合には, (1)水深 15〜 $18 \mathrm{~m}$ 近傍から流れが先行して 微弱となること, (2)その後, 水深 $10 \mathrm{~m}$ 以浅の流れがほぼ 
停止状態となること, (3)次いで, 海面から海底面まで一 様な微速状態が短時間出現することなどが小潮時 (10月 4 日）を対象とした ADCPを用いた観測結果より明らか となった。

これらの知見をもとに，小潮時の潮止りの時刻を予測 する方法について検討した。まず，(1)の現象に対応する 箇所を図一 5 および図一 6 の中から読み取った。すなわ ち, 水深 $17 \mathrm{~m}$ に着目し, そこでの流速の絶対值が $7 \mathrm{~cm} /$ $\mathrm{s}$ 以下となる箇所は両図中の $\mathrm{A}$ 点に対応し, その出現時 刻は 13：06であった. 次いで, (3)の現象に対応する箇所 は, 両図の B ( : 潮止り, 特に図一6の網掛け部分) であ り,その出現時刻は $13: 16 〜 13: 18$ となっている.この ような一連の現象（1) $\rightarrow$ (2) $\rightarrow$ (3)）が小潮時には必ず出現 するものと仮定すれば，A 点が出現して B (：潮止り） が確認されるまでの経過時間 ( $T_{*}=10 \sim 12$ 分) は, ほぼ 一定と考えられる。したがって, 海底面上 $5 \mathrm{~m}$ における 調和解析に基づく予測値に $T$ *を加えた值を「ADCP の 観測結果に基づく潮止りの予測值」とすることが可能で ある。

\section{（2）大島大橋 $3 \mathrm{P}$ および $4 \mathrm{P}$ ケーソン施エへの適用}

上述したような考え方に従い， $3 \mathrm{P}$ および $4 \mathrm{P}$ ケーソン 設置時の潮止りの時刻を予測した。予測值を示す表一1 には，検証の目的からケーソン設置当日（3P：10月 31 日，4P：11月 16 日）に ADCPによって実測された潮止 りの出現時刻（潮止りの実測值）および調和解析に基づ
く予測值も併記されている. 寺島水道のように流れが 3 次元的な構造を有する海域では, ADCP の観測結果に基 づく予測值の方が当日の潮止りの時刻(潮止りの実測值) に極めて近いことが表一1より明らかである.

また, 潜水・張石・均しの作業限界条件としては, 最 大潮流速 (平均值) が $50 \mathrm{~cm} / \mathrm{s}$ と定められている（安達・ 遠藤, 1991). 図一5において, 海面から海底面まで潮流 が $50 \mathrm{~cm} / \mathrm{s}$ 以下となるのは $12: 20 \sim 12: 25$ 以降である. 一方, 海面下 $2 \mathrm{~m}$ での調和解析に基づく予測值では 11 : 20 以降となっており, 予測值と実測值との間には約 60 分程度の遅れが存在していることが分かった。このよう な時間差を考慮し, $3 \mathrm{P}$ および $4 \mathrm{P}$ ケーソン設置当日の潜 水作業開始時刻をそれぞれ $9: 40$ および $9: 00$ と計画し た. 当日の潜水作業は, 図-7および図-8に示される時 間帯（両図中の(1)）に行われた。 なお，両図中に示され る(1)〜(4)の作業内容は表一 2 に示すとおりである.ケー ソン設置当日は, 起重機船の北側海域で ADCPによる潮

表一1 小潮時の潮止りに関する予測値と実測值との比較

\begin{tabular}{|c|c|c|c|c|}
\hline \multirow{2}{*}{ 観測日 } & \multicolumn{2}{|c|}{ 調和解析による予測值 } & \multirow{2}{*}{$\begin{array}{c}\text { ADCP の観測結 } \\
\text { 果に基づく潮止 } \\
\text { りの予測値 }\end{array}$} & \multirow{2}{*}{$\begin{array}{c}\text { ADCP の観測結 } \\
\text { 果に基つ潮止 } \\
\text { の実測値 }\end{array}$} \\
\hline & 海底面上 $5 \mathrm{~m}$ & 海水面下 $2 \mathrm{~m}$ & & \\
\hline 10月 4 日 & $12: 18$ & $12: 26$ & & $13: 16 \sim 13: 18$ \\
\hline 10月31日 & $9: 37$ & $9: 41$ & $9: 47 \sim 9: 49$ & $10: 36 \sim 10: 39$ \\
\hline 11月16日 & $10: 33$ & $10: 16$ & $10: 43 \sim 10: 44$ & $10: 39 \sim 10: 41$ \\
\hline
\end{tabular}

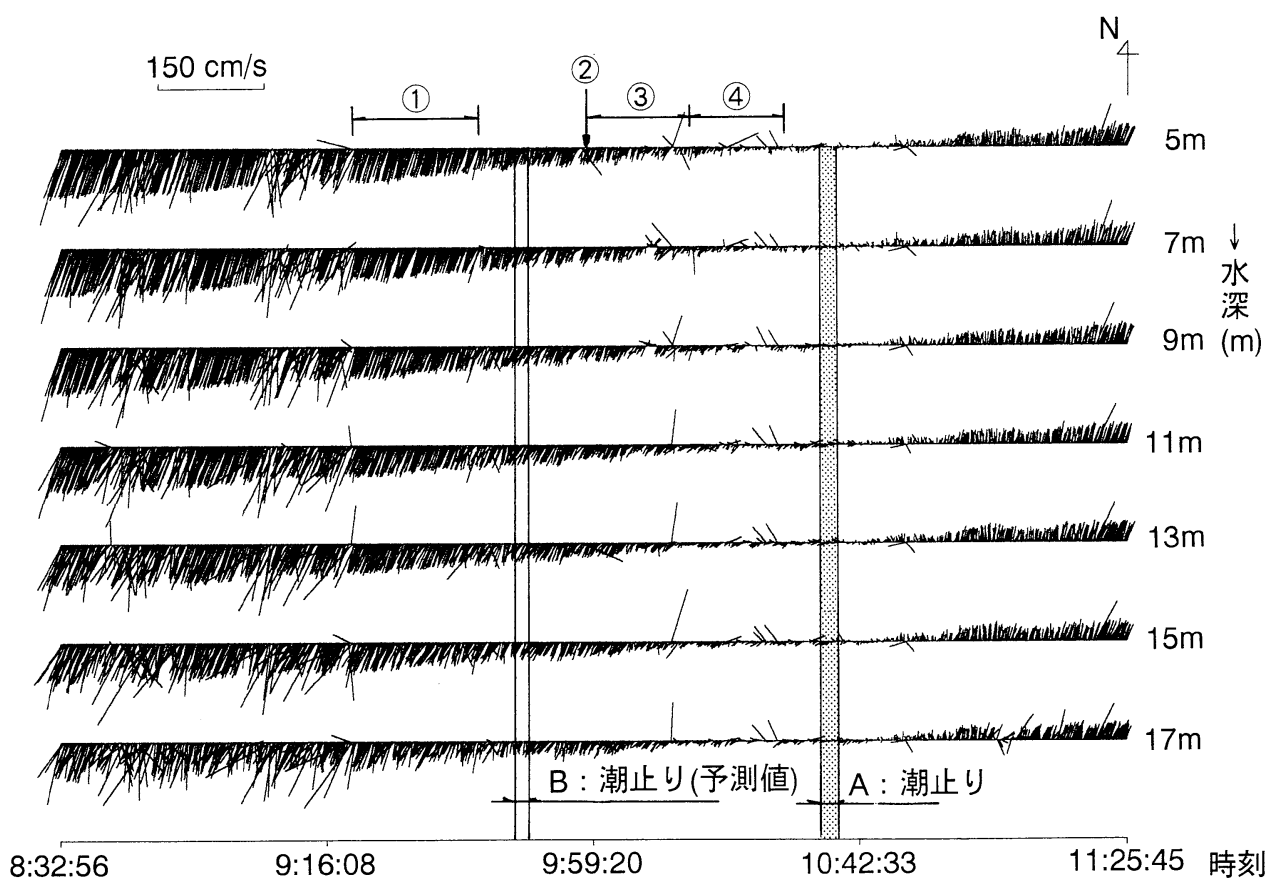

図一7 3P ケーソン設置時の流速ベクトルの時間的変化（10月 31 日） 


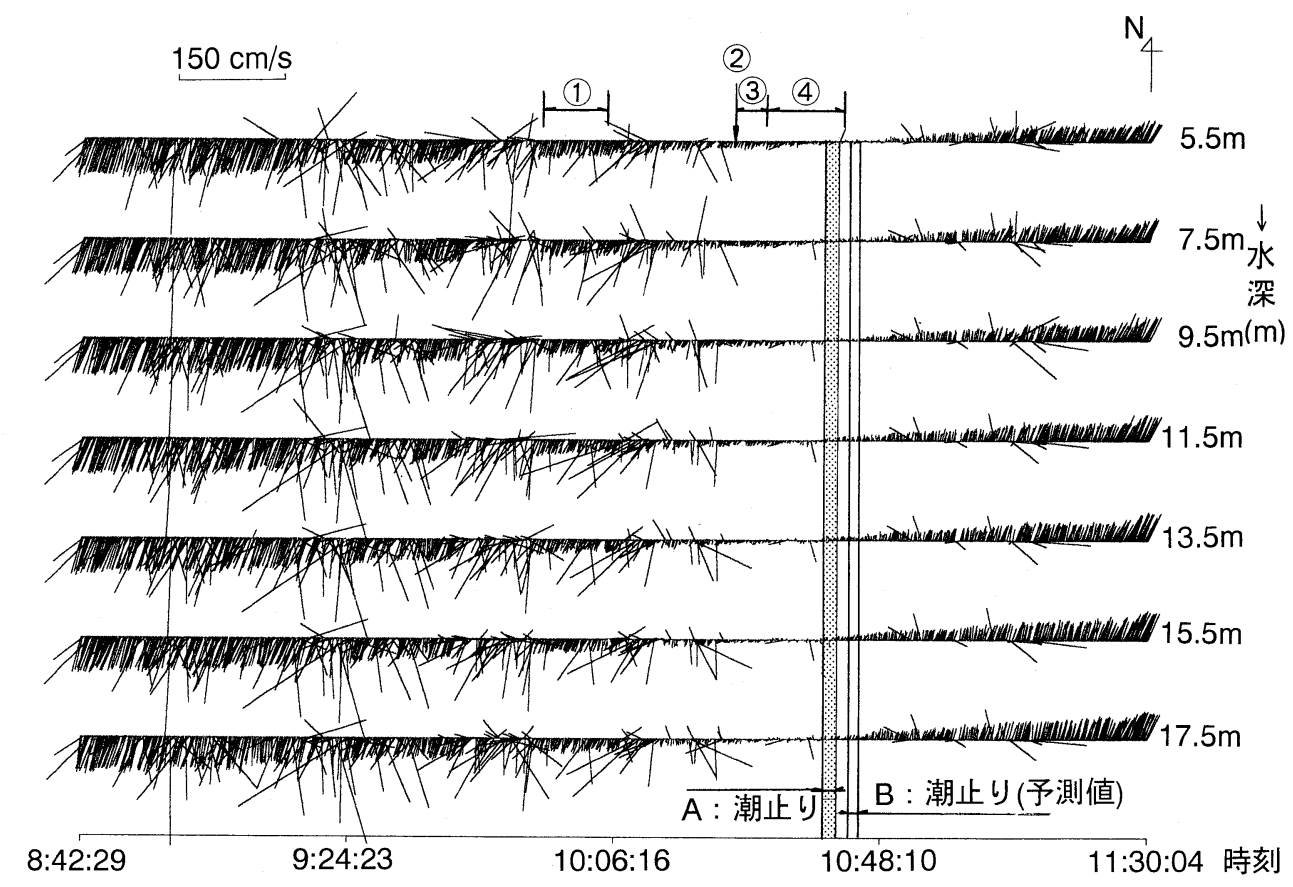

図一8 4P ケーソン設置時の流速ベクトルの時間的変化（11月 16 日）

表一2 $3 \mathrm{P}$ および $4 \mathrm{P}$ ケーソン設置当日の作業内容

\begin{tabular}{|c|c|c|}
\hline 作業項目 & $3 \mathrm{P}(10$ 月 31 日) & $4 \mathrm{P}$ (11月 16 日) \\
\hline $\begin{array}{l}\text { (1)ダイバーにて状況確認 } \\
\text { (2)ケーソン着底 } \\
\text { (3)荷重解放 }(100 \% \rightarrow 50 \%) \\
\text { (4)荷重解放 }(50 \% \rightarrow 0 \%)\end{array}$ & $\begin{array}{c}9: 20 \sim 9: 41 \\
9: 58 \\
9: 58 \sim 10: 15 \\
10: 15 \sim 10: 30\end{array}$ & $\begin{array}{c}9: 55 \sim 10: 05 \\
10: 25 \\
10: 25 \sim 10: 30 \\
10: 30 \sim 10: 40\end{array}$ \\
\hline
\end{tabular}

流観測を実施し, リアルタイムに流況変化を捉え, 潜水 作業にとって有用な技術情報を提供した。そのようなリ アルタイムの情報をもとにケーソンの実施工が遂行され たため, 当日の潜水作業開始は計画した時間より前後す る結果になったものと考えられる。

\section{5. おわりに}

$\mathrm{ADCP}$ を用いた観測から, 寺島水道の潮流が 3 次元的 な流況特性を呈していることが明らかとなった。また， 複雑な海底地形を有する海峡部や水道の流況特性を把握 するためには, 従来から行われてきた海面付近での潮流 観測に加えて, 少なくとも海底面近傍での潮流観測をも 実施する必要性があることも分かった.さらに, 本研究
で提案した ADCP の観測に基づく潮止り時刻の予測方 法は，橋脚ケーソン設置の支援ツールとして有用である ことも確認できた。

最後に, 今回の潮流観測を快く承諾して頂き, 終始ご 協力頂いた長崎県大瀬戸土木事務所並びに西松建設・西 海建設特定建設工事 JV の関係各位に対し感謝申し上げ ます。また，観測は「裕西丸」西尾国作船長の多大な援 助によって遂行できた。さらに, ADCP 用可動架台の製 作および現場取付では（有）山口商事の小野昭二氏に, ADCP の観測データ整理・作図では（株）エス・イー・ エー並びに海面下 $2 \mathrm{~m}$ での潮流観測では（株）シャトー 海洋調査の皆様からのご協力を頂いた.ここに記して謝 意を表します。

\section{参 考 文 献}

安達逸雄・遠藤聖五郎 (1991)：最新港湾工事施工技術, 山海堂, $63 \mathrm{p}$.

杉山陽一・藤原建紀・中辻啓二・福井真吾 (1995)：ADCP によ る伊勢湾の流動構造調査, 海岸工学論文集, 第 42 巻, pp. 1096-1100.

藤原建紀・高杉由夫・肥後竹彦 (1989)：超音速ドップラーによ る沿岸域の流れの可視化, 海洋調査技術 1 (1), pp. 57-65. 